\title{
Lack of training in biodefense research leading to dangerous leaks
}

In February 2006, a researcher at Texas A\&M University came down with brucellosis - a cattle disease that can cause fever and recurring sweats in peopleafter disinfecting a chamber used to expose mice to the bacteria.

She was later found to lack both the authorization and training needed to work with the pathogen. In April 2006, the university found that three other researchers in a different lab had been exposed to the bacteria that cause $Q$ fever.

Labs that work with dangerous microbes are required to report accidents to the US Centers for Disease Control and Prevention (CDC) within a week, but the university waited until April 2007 to inform the agency, and even then only under pressure from the Sunshine Project, a watchdog group that had uncovered the incidents by filing freedom of information requests.

In late June, the CDC shut down the labs.

The workers have since fully recovered, but critics say the slip-ups are symptomatic of widespread lapses in lab safety worldwide. "The issues at Texas A\&M really represent the tip of the iceberg," says Richard Ebright, a biodefense expert at Rutgers University. In August, for instance, the UK announced that the virus that caused an outbreak of foot-and-mouth disease had almost certainly escaped from a nearby lab. In 2004, two researchers at Beijing's National Institute of Virology contracted severe acute respiratory syndrome, infecting seven other people and killing one. Later that year, a Russian scientist died after accidentally injecting herself with the Ebola virus.

Critics say such mishaps are the inevitable consequence of a rapid expansion in biodefense research combined with too little federal oversight and training.

In the US alone, funding for biodefense has skyrocketed from $\$ 576$ million in 2001 to more than $\$ 5$ billion this year, contributing to the construction of new buildings and attracting thousands of scientists.

More than 14,000 researchers at 327 insitutions are approved to work with the most dangerous pathogens. And thousands more will be needed to staff another 32 high-security labs that are planned,

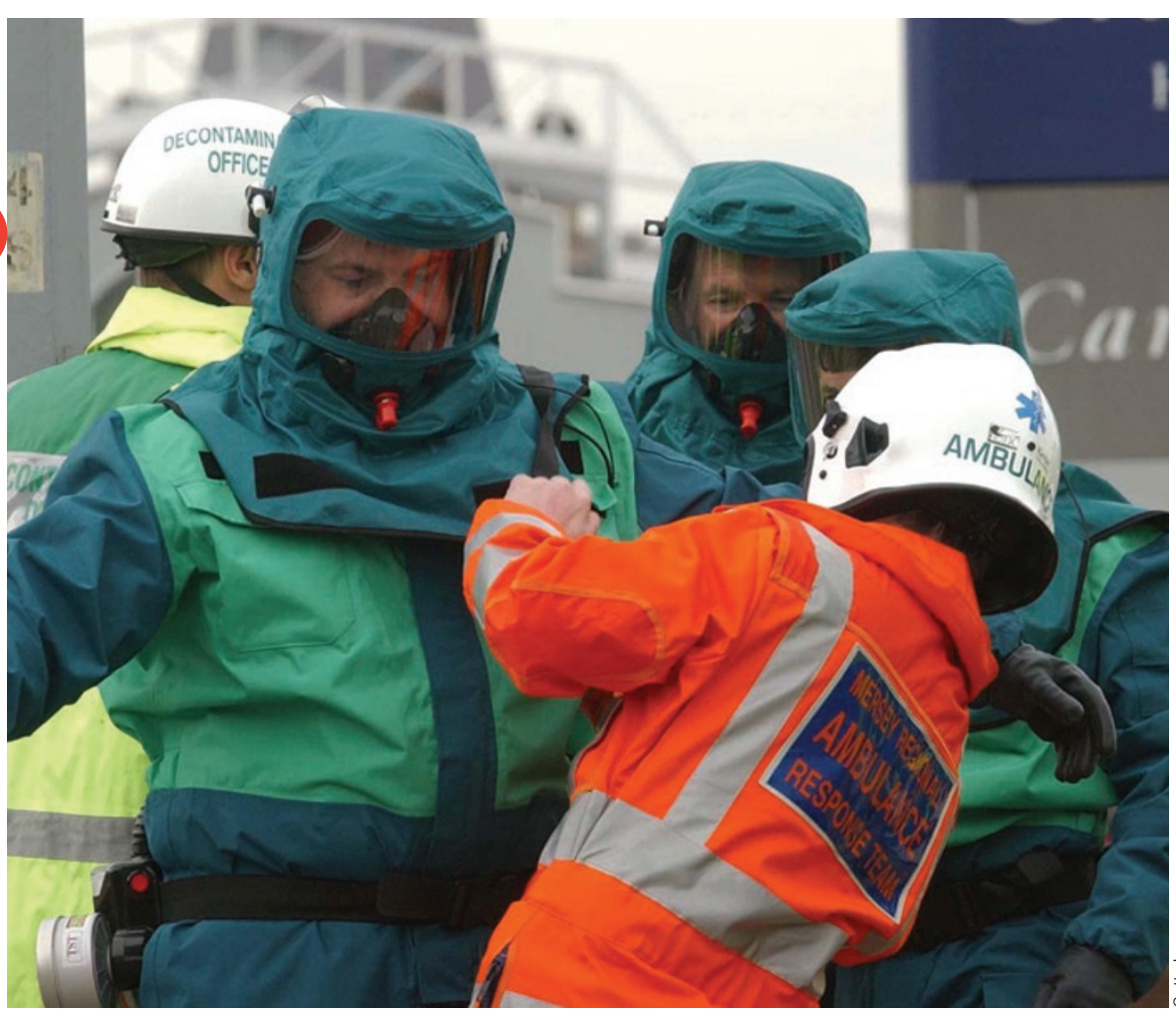

Lethal lapses: Massive boosts in the funding for biodefense research are bringing untrained scientists into contact with deadly microbes. including at least 5 that will house lifethreatening pathogens.

"It's a shift for workers that are going into the biodefense world," says Gigi Kwik Gronvall, a senior associate in the Center for Biosecurity at the University of Pittsbugh Medical Center. "I'm concerned they're not being given the tools to protect themselves."

Although the CDC requires training for people who work with the deadliest microbes-those that cause Ebola, the plague and brucellosis, for example-the burden of providing the training falls to individual labs.

As a result, training schemes can vary wildly.

For instance, at the University of Texas Medical Branch, trainees must pass a written test and a physical examination before they are allowed in a secure lab and must log 100 hours under supervision before they can work alone.

The rules are different at the Southwest Foundation for Biomedical Research in San Antonio.

"There were no guidelines when we got started [in 2000], so we just used common sense for the most part," says Jean Patterson, who oversees the highcontainment lab there. For example, new recruits are made to recite the names of state capitals the first time they put on their protective suit "to make sure they're not wigging out," she says.

Those seeking more rigorous preparation have a few options. The University of Texas Medical Branch offers training in its high-containment labs to outside researchers. But because trainees must first be cleared by the US Department of Justice, the program has had few recruits.

Emory University's program, which relies on a mock high-containment facility, has had more success, last year training more than 50 researchers from the US, Switzerland, Thailand and Pakistan.

Still, these programs can't cope with the large number of researchers expected to enter the field. "There just are not anywhere near enough experienced people to go around," notes Karl Johnson, a retired virologist who established the first CDC lab for lethal airborne viruses. "There's going to be an awful lot of on-thejob training."

Cassandra Willyard, New York 